\title{
A CROSS-SECTIONAL STUDY OF HEPATITIS B AND HEPATITIS C KNOWLEDGE AMONG DENTAL MEDICINE STUDENTS AT THE UNIVERSITY OF ZAGREB
}

\author{
Jan Homolak ${ }^{1}$, Deni Tomljanović2, Milan Miloševićc ${ }^{3}$, Domagoj Vražićc, Mario Živkovićs, \\ Ivan Budimir ${ }^{5,6}$, Borka Pezo Nikolićc,, Antonela Muslim ${ }^{8}$, Neven Ljubičićc ${ }^{5,6,9}$ and Marko Nikolićs,9 \\ ${ }^{1}$ Department of Pharmacology, University of Zagreb School of Medicine, Zagreb, Croatia; \\ ${ }^{2}$ University of Zagreb School of Dental Medicine, Zagreb, Croatia; \\ ${ }^{3}$ Department of Environmental and Occupational Health and Sports, Andrija Štampar School of Public Health, \\ University of Zagreb School of Medicine, Zagreb, Croatia; \\ ${ }^{4}$ Department of Periodontology, University of Zagreb School of Dental Medicine, Zagreb, Croatia; \\ ${ }^{5}$ Gastroenterology and Hepatology Division, Sestre milosrdnice University Hospital Centre, Zagreb, Croatia; \\ ${ }^{6}$ Department of Internal Medicine, University of Zagreb School of Medicine, Zagreb, Croatia; \\ ${ }^{7}$ Cardiovascular Division, Zagreb University Hospital Centre, Zagreb, Croatia; \\ ${ }^{8}$ Gastroenterology Unit, Dr. Ivo Pedišić General Hospital, Sisak, Croatia; \\ ${ }^{9}$ Department of Internal Medicine, University of Zagreb School of Dental Medicine, Zagreb, Croatia
}

SUMMARY - Dental health care workers, particularly dental medicine students (DMS), are at an increased risk of hepatitis $\mathrm{B}$ virus $(\mathrm{HBV})$ and hepatitis $\mathrm{C}$ virus $(\mathrm{HCV})$ infection. The aim of our study was to assess the level of knowledge on HBV and HCV, estimate needlestick injury (NSI) prevalence and reporting practice in DMS at the University of Zagreb, and analyze how enrolment in obligatory and supplemental courses affects knowledge and NSI reporting practice. The knowledge was assessed by our questionnaires based on the Centers for Disease Control general handouts. Additional information was collected to examine the prevalence and reporting practice of NSI. Data were analyzed by descriptive statistical analysis, independent-samples t-test, proportion analyses, and combined factor analyses of categorical and quantitative variables in SPSS and R. In total, $206 \mathrm{stu}-$ dents participated in the survey. The overall level of HBV- and HCV-related knowledge was poor, with the mean scores of $61.90 \%$ and $51.35 \%$, respectively. Moreover, students enrolled in the first year demonstrated significantly lower levels of knowledge in comparison with their older peers. Of all participants, $18.2 \%$ had sustained a NSI and the majority of them (78.95\%) had never reported the injury. In conclusion, DMS have low levels of knowledge on important occupational pathogens and poor NSI reporting practice. Moreover, formal education in the current form has failed to significantly improve student competence and theoretical knowledge translates poorly into more conscientious injury reporting practice. We should look for a better way to increase student awareness and level of knowledge on this topic.

Key words: Hepatitis B; Hepatitis C; Dental education; Needlestick injury; Occupational pathogens; Occupational health

\section{Introduction}

Hepatitis $\mathrm{B}$ virus (HBV) and hepatitis $\mathrm{C}$ virus $(\mathrm{HCV})$ infections are one of the major global health problems that induce considerable morbidity and
Correspondence to: Jan Homolak, MD, Department of Pharmacology, School of Medicine, University of Zagreb, Šalata 11, HR-10000 Zagreb, Croatia

E-mail: homolakjan@gmail.com

Received June 15, 2020, accepted July 17, 2020 
mortality worldwide, often through the consequences of chronic infection ${ }^{1,2}$. Recent estimates of the number of people chronically infected with HBV range from 240 to 350 million, and it is believed that more than 2 billion people have been infected with the virus ${ }^{1}$. For $\mathrm{HCV}$, the estimated number of infections based on recent increases in seroprevalence is $>185$ million infections worldwide 3 .

According to the Institute for Health Metrics and Evaluation Global Burden of Disease Study from 2017, HBV was estimated to have resulted in 799007 deaths, with 89589 of these attributable to acute infection, 383971 caused by cirrhosis and other chronic liver diseases due to HBV, and 325447 caused by liver cancer. For $\mathrm{HCV}$, the estimated number of deaths was 580 051, with 3472 deaths caused by acute infection, 342243 caused by cirrhosis and other chronic liver diseases, and 234336 caused by liver cancer. The estimated number of Disability-Adjusted Life Years (DALYs) was $2.53 \mathrm{E}+07$ and $1.56 \mathrm{E}+07$ for $\mathrm{HBV}$ and $\mathrm{HCV}$, respectively ${ }^{4}$.

Health care workers (HCW) are considered to be among the groups at an increased risk of both HBV and $\mathrm{HCV}$ infection ${ }^{5,6}$. Moreover, there is some evidence that dental health care workers (DHCW) are at an even greater risk of infection than other HCW. Pre-vaccination studies report a three to six times greater $\mathrm{HBV}$ infection rate among $\mathrm{DHCW}$ in comparison to the general population, being highest among $\mathrm{HCW}^{7,8}$.

Health care students (HCS) are an especially important population at an increased risk of HBV and $\mathrm{HCV}$ infection because of the lack of practical and theoretical knowledge during the first encounter with the patient in the clinical setting. Moreover, among HCS, dental students seem to be at the highest risk, possibly due to the greater number of percutaneous injuries in comparison to other $\mathrm{HCS}^{8-11}$, or poor compliance with guidelines for infection control in a highrisk dental setting ${ }^{12,13}$.

Based on our subjective experience, students enrolled in entry-level clinical years have inadequate knowledge regarding bloodborne pathogens and occupational disease, which puts them at a higher risk of infection. As we believe this to be is of great importance, we decided to try to objectively and quantitatively assess the problem and investigate the effectiveness of our elective course as a tool that is currently used to solve it.
The aim of this study was to objectively assess HBV- and HCV-related knowledge of dental medicine students at our university. Moreover, we wanted to estimate the prevalence of needlestick injuries in our students and evaluate whether injuries were officially reported and properly treated. Finally, we wanted to evaluate the effect of our elective supplementary course Occupational Diseases in Dentistry designed to reinforce the knowledge of the important bloodborne pathogens and other potential occupational hazards in dentistry.

\section{Subjects and Methods}

A cross-sectional analytical study was conducted in the University of Zagreb School of Dental Medicine students by means of an anonymous questionnaire. All students were informed about the aims of the study and informed consent was obtained from all participants. The students were allowed to withdraw from the study at any time point without repercussions. The study was approved by the Ethics Committee of the University of Zagreb School of Dental Medicine. The questionnaire consisted of 4 parts.

The first part consisted of questions about the sociodemographic status and general education-related information (gender, age, year of study, high school education, and status of completion of the Internal Medicine Course and Occupational Diseases in Dentistry course). The second part of the questionnaire assessed student knowledge about HBV based on 36 questions created to assess their knowledge based on the Centers for Disease Control and Prevention (CDC) information intended for the general public in order to exclude the curse of the knowledge cognitive bias. The third part of the questionnaire assessed student knowledge about HCV based on 30 questions created in the same way as described for HBV. The fourth part of the questionnaire consisted of questions for evaluation of the prevalence of needlestick injuries and knowledge about injury management. In the $\mathrm{HBV}, \mathrm{HCV}$, and needlestick injury knowledge sections, correct answers were scored 1 point, whereas incorrect answers and conscious lack of knowledge received 0 points. The scores were summed up to obtain general $\mathrm{HBV}$ - and $\mathrm{HCV}$-related knowledge scores for each student. 
Table 1. Descriptive statistics of the study sample of dentistry students

\begin{tabular}{|c|c|c|c|}
\hline & & $\mathrm{n}$ & $\%$ \\
\hline \multirow[t]{2}{*}{ Gender } & Male & 41 & 19.9 \\
\hline & Female & 165 & 80.1 \\
\hline \multirow[t]{6}{*}{ Current year of study } & 1 & 50 & 24.3 \\
\hline & 2 & 40 & 19.4 \\
\hline & 3 & 24 & 11.7 \\
\hline & 4 & 14 & 6.8 \\
\hline & 5 & 24 & 11.7 \\
\hline & 6 & 54 & 26.2 \\
\hline \multirow[t]{4}{*}{ Completed high school } & $\begin{array}{l}\text { Classical high school/high school } \\
\text { with extended language curriculum }\end{array}$ & 20 & 9.7 \\
\hline & General high school & 143 & 69.4 \\
\hline & $\begin{array}{l}\text { High school with extended natural } \\
\text { sciences and mathematics curriculum }\end{array}$ & 39 & 18.9 \\
\hline & Vocational school & 4 & 1.9 \\
\hline \multirow[t]{2}{*}{ Passed Internal Medicine Exam } & No & 114 & 55.3 \\
\hline & Yes & 92 & 44.7 \\
\hline \multirow{2}{*}{$\begin{array}{l}\text { Passed Occupational Diseases } \\
\text { in Dentistry Exam }\end{array}$} & No & 148 & 71.8 \\
\hline & Yes & 58 & 28.2 \\
\hline \multirow[t]{2}{*}{ Sustained a needlestick injury } & No & 168 & 81.6 \\
\hline & Yes & 38 & 18.4 \\
\hline
\end{tabular}

Statistical analysis was done by means of descriptive statistical analysis and independent-samples t-test with IBM SPSS Statistics 25.0. Additional exploratory statistical analysis and data visualization was conducted with R Statistical Software version 3.6.1. In short, visualization and calculation of the proportions of answers for both $\mathrm{HCV}$-related knowledge and $\mathrm{HBV}$-related knowledge questionnaire was done with Likert package. Factor analysis of mixed data (FAMD) was based on FactoMineR (v. 2.2) package and was separately conducted on all questions from $\mathrm{HCV}$ - and $\mathrm{HBV}$-related knowledge questionnaires in the context of overall knowledge data and information related to the year of study, gender, and course completion status. Additional FAMD was conducted on quantitative variables of overall hepatitis-related knowledge and in the context of the information related to needlestick injury knowledge and reporting. FAMD variables were visualized with regard to the first two dimensions and final FAMD analysis was additionally reported by the individual factor map, a graph of categories, and quantitative variables.

\section{Results}

The questionnaire was completed by 206 students ( $80.1 \%$ female and $19.9 \%$ male). There were 90 preclinical (currently enrolled in the $1^{\text {st }}$ and $2^{\text {nd }}$ year of study) and 116 clinical (currently enrolled in the $3^{\text {rd }}$, $4^{\text {th }}, 5^{\text {th }}$, or $6^{\text {th }}$ year of study) students. The majority of students (69.4\%) had previously completed general high school, 18.9\% high school with extended natural sciences and mathematics curriculum, 9.7\% classic high school/high school with extended language curriculum, and $1.9 \%$ vocational school. The Internal Medicine Exam (IME) was passed by $55.3 \%$ and the Occupational Diseases in Dentistry Exam (ODDE) by $28.2 \%$ of the examined students. Descriptive statistical representation of the examined sample is reported in Table 1.

\section{Hepatitis B-related knowledge}

After the total of 36 questions related to HBV infection had been scored as described in the Methods section, the overall score was statistically analyzed by 
Table 2. Estimated knowledge related to hepatitis B virus (HBV) among dentistry students based on difference in the absolute number of correct answers analyzed by independent-samples t-test

\begin{tabular}{|l|l|l|l|l|l|l|}
\hline \multicolumn{6}{|c|}{ Number of correct answers to HBV-related questions (out of 36) } \\
\hline \multirow{5}{*}{ Current year of study } & 1 & $n$ & Mean & SD & \% of total number & \\
& 2 & 40 & 12.86 & 6.58 & 35.7 & \\
& 3 & 24 & 24.75 & 4.16 & 68.8 & \multirow{2}{*}{} \\
& 4 & 14 & 24.29 & 7.38 & 67.5 & \\
\hline \multirow{3}{*}{ Gender } & 5 & 24 & 24.04 & 3.59 & 66.8 & \\
\hline \multirow{2}{*}{ Passed Internal Medicine Exam } & 6 & 54 & 24.44 & 5.50 & 67.9 & \multirow{2}{*}{0.312} \\
\hline Passed Occupational Diseases & Male & 41 & 22.41 & 8.87 & 62.3 & $<0.001$ \\
in Dentistry Exam & Female & 165 & 21.13 & 6.80 & 58.7 & $<0.001$ \\
\hline
\end{tabular}
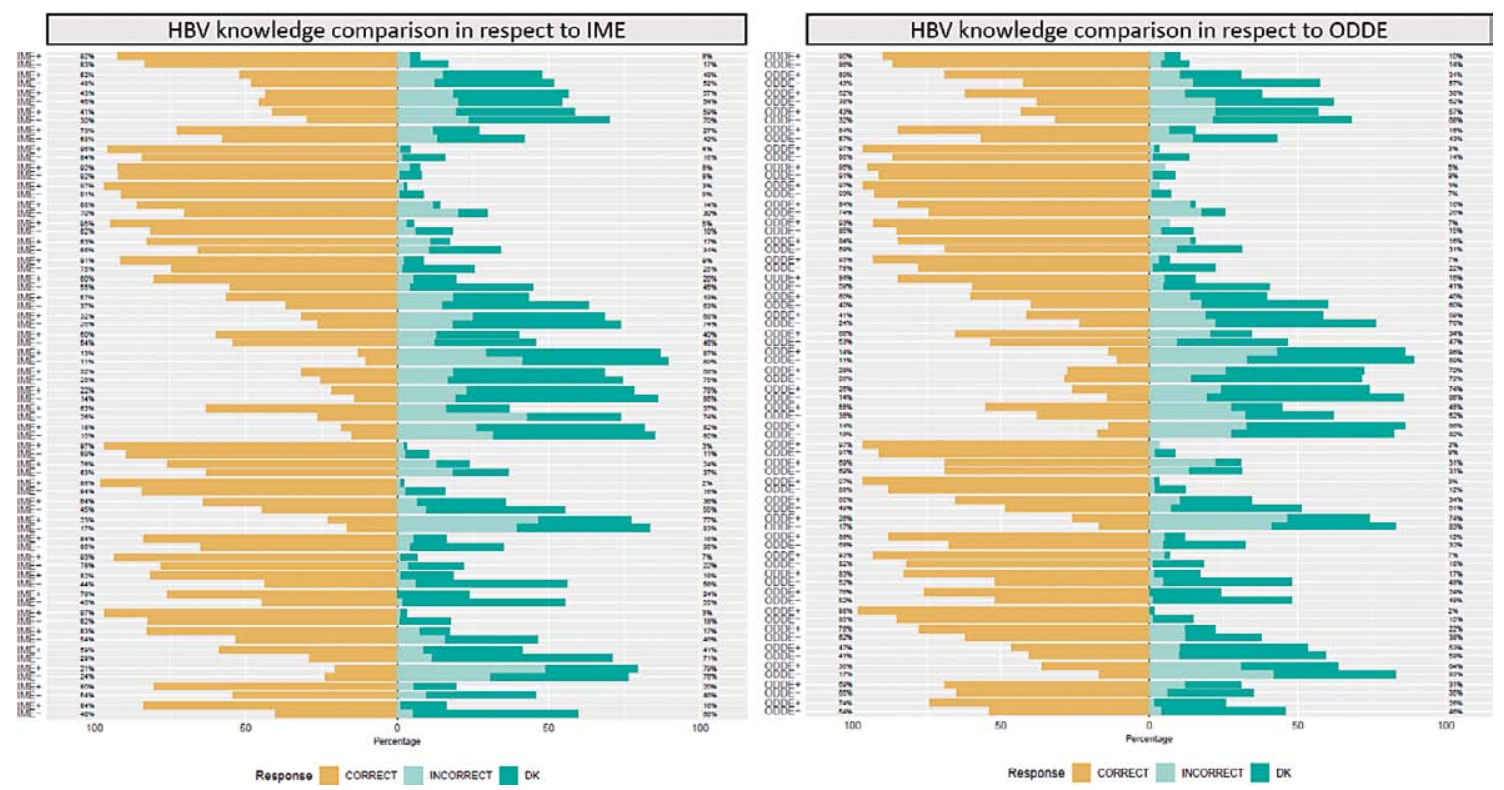

Fig. 1. Comparison of answers to all questions on HBV in regards to the status of Internal Medicine Exam completion $(I M E+/-)$ and Occupational Diseases in Dentistry Exam completion (ODDE+/-). Proportions of correct and incorrect answers are presented. „I don't know" (DK) answer representing conscious lack of knowledge was treated as incorrect, but due to its importance discussed in the text, it was presented separately from the incorrect answers. The list of all questions is provided in the Appendix.

independent-samples t-test in order to evaluate difference in the absolute number of correct answers based on the participant current year of study, gender, and status of IME and ODDE completion. Statistical analysis revealed a difference in the HBV-related knowledge of students enrolled in the first year in comparison to the knowledge of students enrolled in all other years (35.7\% vs. 64.7/68.8/67.5/66.8/67.9\%; 
Table 3. Estimated knowledge related to hepatitis $C$ virus (HCV) among dentistry students based on difference in the absolute number of correct answers analyzed by independent-samples t-test

\begin{tabular}{|c|c|c|c|c|c|c|}
\hline \multicolumn{7}{|c|}{ Number of correct answers to HCV-related questions (out of 30) } \\
\hline & & $\mathrm{n}$ & Mean & $\mathrm{SD}$ & $\%$ of total number & \\
\hline \multirow{6}{*}{ Current year of study } & 1 & 50 & 10.76 & 4.24 & 35.9 & \multirow{6}{*}{$<0.001$} \\
\hline & 2 & 40 & 15.20 & 4.08 & 50.7 & \\
\hline & 3 & 24 & 16.04 & 3.61 & 53.5 & \\
\hline & 4 & 14 & 17.86 & 3.44 & 59.5 & \\
\hline & 5 & 24 & 16.33 & 2.65 & 54.4 & \\
\hline & 6 & 54 & 16.24 & 4.24 & 54.1 & \\
\hline \multirow{2}{*}{ Gender } & Male & 41 & 15.73 & 4.70 & 52.4 & \multirow{2}{*}{0.146} \\
\hline & Female & 165 & 14.58 & 4.51 & 48.6 & \\
\hline \multirow{2}{*}{ Passed Internal Medicine Exam } & $\mathrm{Ne}$ & 114 & 13.47 & 4.68 & 44.9 & \multirow{2}{*}{$<0.001$} \\
\hline & $\mathrm{Da}$ & 92 & 16.46 & 3.82 & 54.9 & \\
\hline \multirow{2}{*}{$\begin{array}{l}\text { Passed Occupational Diseases } \\
\text { in Dentistry Exam }\end{array}$} & $\mathrm{Ne}$ & 148 & 14.31 & 4.67 & 47.7 & \multirow{2}{*}{0.012} \\
\hline & $\mathrm{Da}$ & 58 & 16.07 & 4.01 & 53.6 & \\
\hline
\end{tabular}
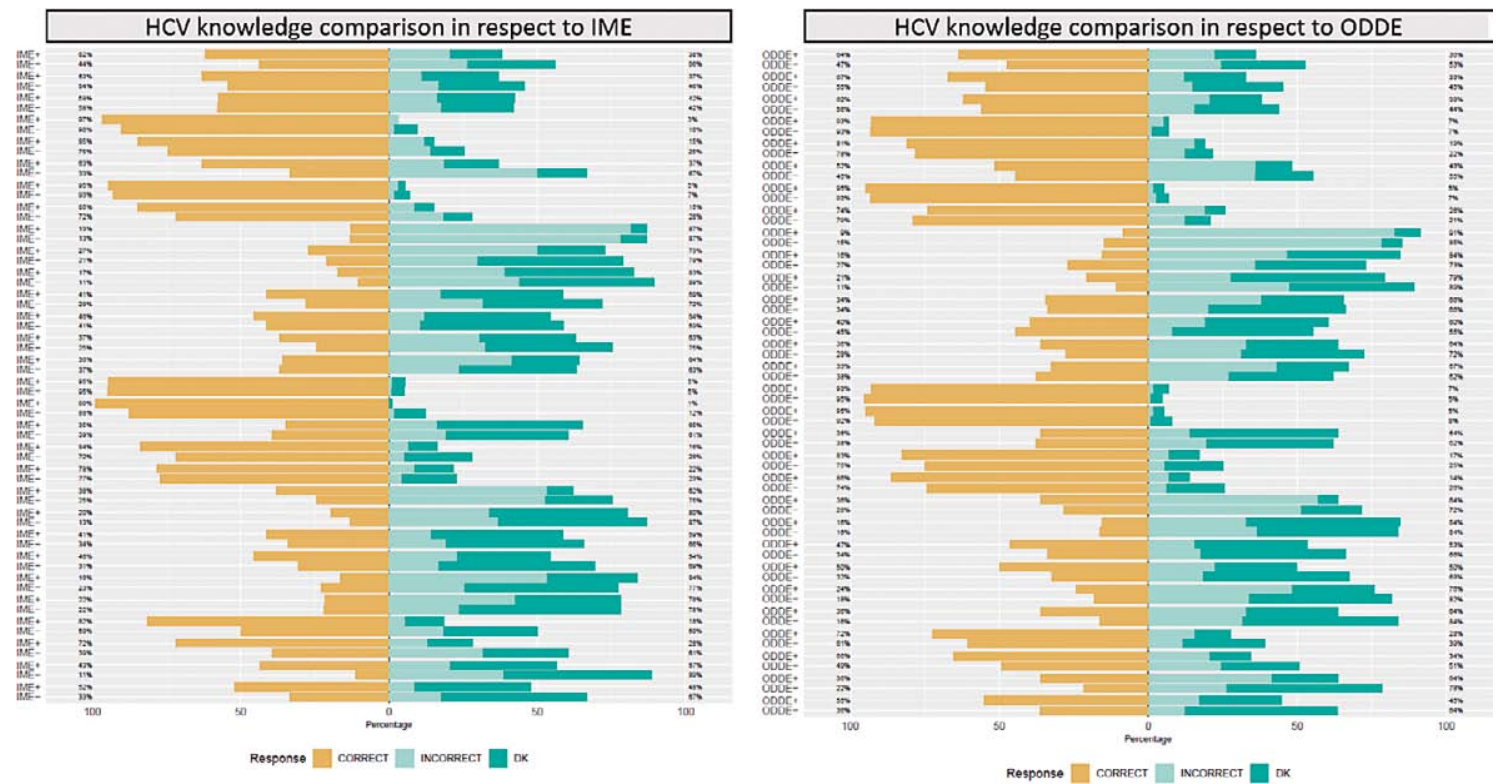

Fig. 2. Comparison of answers to all questions on HCV in regard to the status of Internal Medicine Exam completion (IME+/-) and Occupational Diseases in Dentistry Exam completion (ODDE+/-). Proportions of correct and incorrect answers are presented. „I don't know“ (DK) answer representing conscious lack of knowledge was treated as incorrect, but due to its importance discussed in the text, it was presented separately from the incorrect answers. The list of all questions is provided in the Appendix.

$\mathrm{p}<0.001)$. There was no statistically significant difference in $\mathrm{HBV}$-related knowledge between male and female students (62.3\% vs. 58.7\%; $\mathrm{p}=0.312)$. Students who had passed IME demonstrated better knowledge in comparison to their peers $(67.6 \%$ vs. $52.8 \%$; $\mathrm{p}<0.001$ ), as did students who had passed ODDE (68.7\% vs. 55.8\%; $\mathrm{p}<0.001$ ) (Table 2). Comparison of answers to all questions with corresponding propor- 
Table 4. Prevalence of needlestick injuries and attitude on needlestick injury management

\begin{tabular}{|c|c|c|c|}
\hline & & $\begin{array}{l}\text { Number } \\
\text { of answers }\end{array}$ & Proportion \\
\hline \multirow[t]{3}{*}{ Reported a needlestick injury } & No & 30 & $14.6 \%$ \\
\hline & Yes & 8 & $3.9 \%$ \\
\hline & $\begin{array}{l}\text { I have never sustained } \\
\text { a needlestick injury }\end{array}$ & 168 & $81.6 \%$ \\
\hline \multirow{2}{*}{$\begin{array}{l}\text { In case of a needlestick injury, all ongoing actions should be } \\
\text { stopped }\end{array}$} & No & 62 & $30.1 \%$ \\
\hline & Yes & 144 & $69.9 \%$ \\
\hline \multirow{2}{*}{$\begin{array}{l}\text { During evaluation of the needlestick injury, it is not } \\
\text { important to assess the type of injury (blood contamination, } \\
\text { depth of the puncture wound...) }\end{array}$} & No & 36 & $17.5 \%$ \\
\hline & Yes & 170 & $82.5 \%$ \\
\hline \multirow[t]{2}{*}{ It is recommended to apply pressure to the puncture wound } & No & 131 & $63.6 \%$ \\
\hline & Yes & 75 & $36.4 \%$ \\
\hline \multirow{2}{*}{$\begin{array}{l}\text { It is recommended to rub and apply alcohol to the puncture } \\
\text { wound }\end{array}$} & No & 139 & $67.5 \%$ \\
\hline & Yes & 67 & $32.5 \%$ \\
\hline \multirow{2}{*}{$\begin{array}{l}\text { The risk of infection after a needlestick injury can be } \\
\text { estimated based on the antibody titer }\end{array}$} & No & 79 & $38.3 \%$ \\
\hline & Yes & 127 & $61.7 \%$ \\
\hline
\end{tabular}

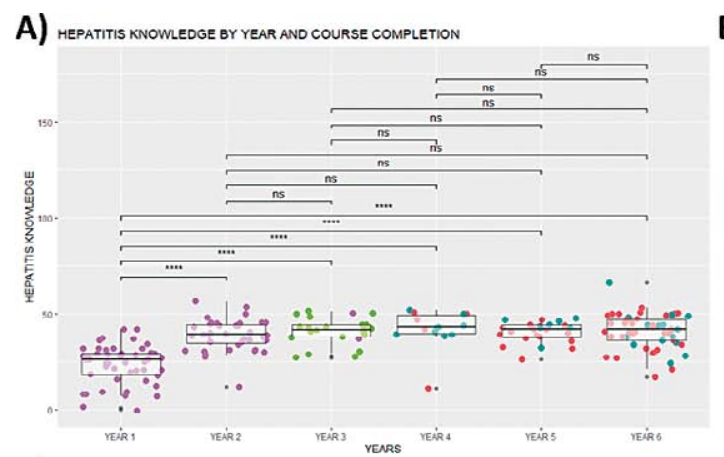

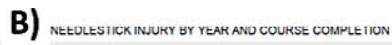
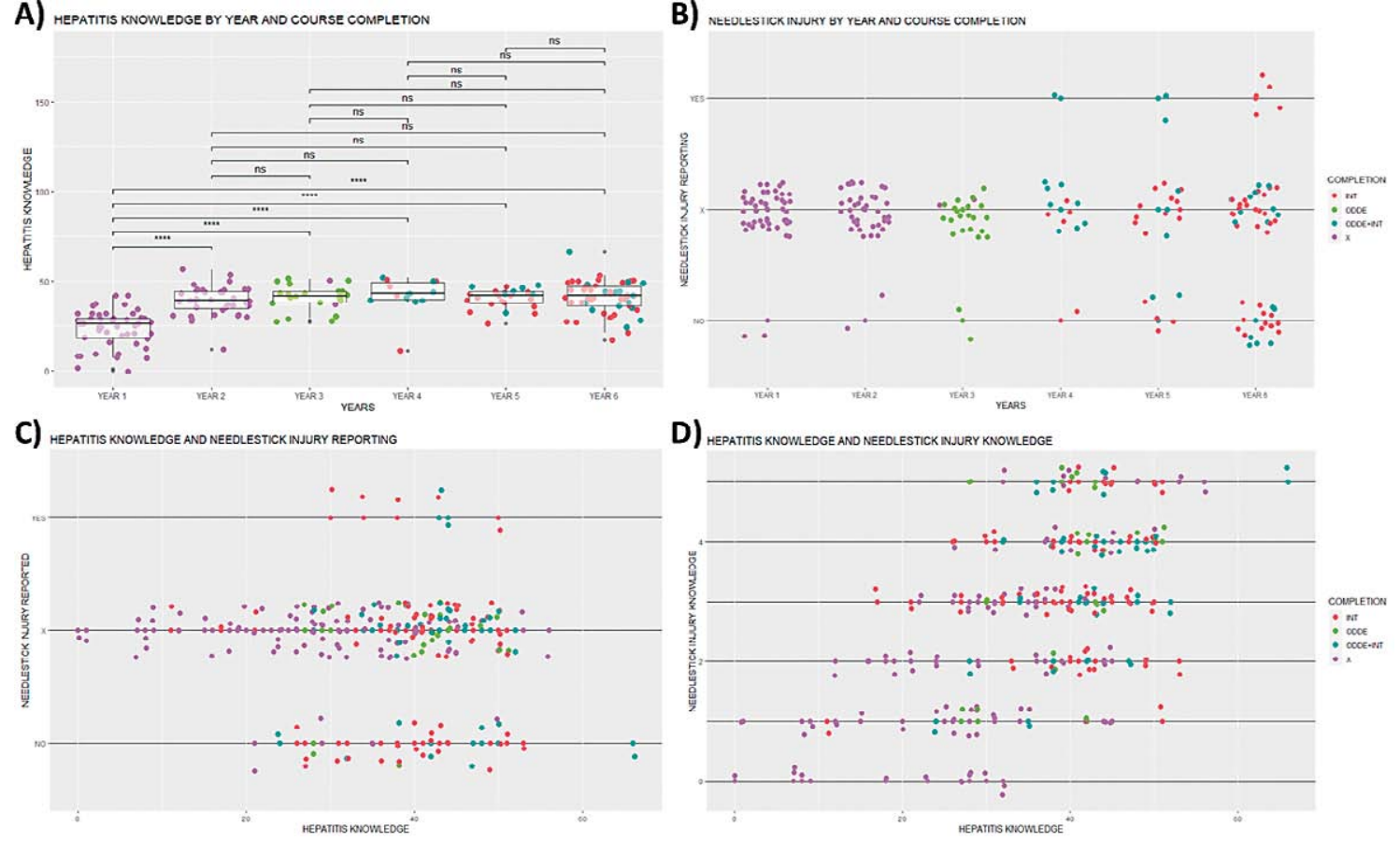

Fig. 3. (A) Visual representation of the distribution of hepatitis-related knowledge by years of study and Internal Medicine Exam/Occupation Diseases in Dentistry Exam (IME/ODDE) completion; (B) proportion of students having sustained and reported a needlestick injury color-coded by course completion status; $(C)$ visual representation of the relationship of the hepatitis-related knowledge with sustaining and reporting a needlestick injury stratified color-coded by course completion status; (D) visual representation of the association between needlestick injury-related knowledge and hepatitis-related knowledge; $* * * * * 0.0001)$. 
tions in relation to IME and ODDE completion is illustrated in Figure 1. The relative contribution of all questions to the overall $\mathrm{HBV}$-related knowledge score and relationships between all questions with categorical variables of interest (gender, IME and ODDE completion, and current year of study) were further explored with FAMD (Appendix).

\section{Hepatitis C-related knowledge}

After the total of 30 questions related to HCV infection had been scored as described in the Methods section, the overall score was statistically analyzed by independent-samples $\mathrm{t}$-test to evaluate difference in the knowledge in the same way as was done for HBVrelated knowledge. Again, first-year students demonstrated significantly less knowledge related to $\mathrm{HCV}$ infection in comparison to their older peers (35.9\% vs. 50.7/53.5/59.5/54.4/54.1\%; $\mathrm{p}<0.001)$. Male students scored slightly better, but the difference did not meet the criteria for statistical significance $(52.4 \%$ vs. $48.6 \%$; $\mathrm{p}=0.146)$. As with HBV, students who had passed IME scored significantly better $(54.9 \%$ vs. $44.9 \%$; $\mathrm{p}<0.001)$, as did the students who had passed ODDE (53.6\% vs. 47.7\%; $\mathrm{p}=0.012$ ) (Table 3). Comparison of answers to all questions with corresponding proportions in relation to completion of IME and ODDE is illustrated in Figure 2. To analyze the relative contribution of all questions to the overall HCV-related knowledge score and relationships between all questions with categorical variables of interest (gender, IME and ODDE completion, and current year of study), data were further explored with FAMD (Appendix).

\section{Needlestick injury}

Of all participants, 38 (18.4\%) students had sustained a needlestick injury, and 30 of them (78.95\%) had never reported the injury. Most of the examined students (69.9\%) think that all ongoing actions should be stopped in case of a needlestick injury. Most of the students (82.5\%) also believe that it is not important to assess the type of injury (blood contamination, depth of puncture wound, etc.) during evaluation of the needlestick injury. One-third of the students (36.4\%) think it is recommended to apply pressure to the puncture wound. One-third of the students $(32.5 \%)$ also think that it is recommended to rub and apply alcohol to the puncture wound. More than half of the participants $(61.7 \%)$ think that the risk of infection after a needlestick injury can be estimated based on the antibody titer (Table 4).

\section{Association of Occupational Disease in Dentistry course completion with injury reporting and hepatitis knowledge}

Finally, in order to see if students having completed the Occupational Diseases in Dentistry course really stand out from their peers by hepatitis-related knowledge and how they handle and report occupational injuries, all data obtained were analyzed by FAMD (graphs of variables, categories, quantitative variable primary component analysis, and individual factor map are available in the Appendix). Moreover, exploratory visualization of hepatitis knowledge according to years of study, course completion status, and needlestick injury reporting was performed (Fig. 3). As the year variable was a significant contributor to the hepatitis knowledge score variable, overall knowledge was plotted by years (Fig. 3A). Interestingly, as also evident from Tables 2 and 3, the overall knowledge was greater in second-year students in comparison to first-year students, but there was no significant difference between students enrolled in the second year and their older peers. Needlestick injury reporting by year and course completion indicated that although fourth and fifth year students having completed ODDE were slightly more likely to be in the group of students who reported the injury in comparison to their peers who had just completed IME, the effect was non-existent in the sixth year students and the overall number of participants was too small to deduce any relevant conclusions (Fig. 3B). Hepatitis-related knowledge and needlestick injury reporting are illustrated in Figure 3C. In contrast to what we expected, the data did not support our hypothesis that there was a greater chance for a student with greater factual knowledge on hepatitis to be more likely to report a needlestick injury. Interestingly, hepatitis-related knowledge was in correlation with needlestick injury-related knowledge (Fig. 3D), indicating that greater awareness of needlestick injury did not translate to more conscientious needlestick injury reporting.

\section{Discussion}

In our study, dentistry students demonstrated an unsatisfactorily low level of knowledge related to im- 
portant bloodborne pathogens, HBV and HCV. Although the whole study was conducted in order to assess current knowledge and provide information for a more effective design of education on occupational diseases and appropriate prevention strategies, and subpar results were expected, we were shocked to find out that the average dental medicine student knew correct answers to just over 55\% of questions in our questionnaire. The questionnaire we used for knowledge evaluation was based on the CDC HBV and $\mathrm{HCV}$ overview documents, basic information handouts intended for the education of the general population (complete questionnaire is available in the Appendix). Nevertheless, on average, students scored just $51.35 \%$ on the HCV-related knowledge test and $61.90 \%$ on the HBV-related knowledge test. Considering the practical importance of the knowledge examined by the questionnaire, we believe the demonstrated knowledge level was insufficient for safe clinical work. For example, only $36.4 \%$ knew that most of the people infected with HCV do not develop symptoms acutely, and only $33.9 \%$ of students knew $\mathrm{HCV}$ is not transmitted through mosquito bites. Hepatitis infection is considered to be one of the most important infectious occupational hazards in dental profession, so we strongly believe that solid knowledge on hepatitis virus transmission and at least superficial knowledge on hepatitis infection symptom timecourse should be obligatory. Moreover, an alarmingly low number of students (16\%) recognized the claim "After being exposed to HCV, for most of the people $\mathrm{HCV}$ antibody blood test will be positive 48 hours after the exposure" as incorrect. In case of injury during clinical rotations or occupational hazards in dental practice, knowledge about $\mathrm{HCV}$ diagnostic tests is of exceptional importance, and a belief that antibody titer is usually positive 48 hours after HCV exposure could lead to type 2 errors with serious medical consequences. Furthermore, hepatitis $\mathrm{C}$ drugs are considered to be a success story in the field of pharmacology with rapidly expanding treatment options and very high cure rates confirmed by data from clinical trials and realworld results ${ }^{14}$ (up to $>95 \%$ cure rate ${ }^{15}$ ), but 4 out of 5 students believe current $\mathrm{HCV}$ treatment can cure only $20 \%$ of people. On top of that, more than $50 \%$ think that, in Croatia, all people born after 1993 (and most of the students enrolled in the study were) were vaccinated against $\mathrm{HCV}$. We believe this is very problem- atic. Although several vaccines are currently under development, the $\mathrm{HCV}$ vaccine is not available yet, as was the case in 1993. Erroneous beliefs that everyone is vaccinated create a false impression of security and probably contribute to poor compliance with guidelines for infection control in the high-risk dental setting. Results from the HBV-related knowledge questionnaire were slightly better, but a troublesome prevalence of incorrect answers to some questions was also observed. For example, $71.4 \%$ of students incorrectly believe that acute HBV infection is always symptomatic and that it always requires hospitalization. Moreover, only $11.6 \%$ know that the risk of chronic infection after exposure is greater in children and young people in comparison to adults. Both claims could lead to misinterpretation of symptoms and inappropriate management after potential exposure to the infected material. On top of that, only $53.4 \%$ of students correctly answered a very practical real-world question on postexposure prophylaxis and knew that postexposure prophylaxis by means of $\mathrm{HBV}$ vaccination can be done in order to decrease the risk of infection preferably in the first 24 hours after exposure. Also, 60.7\% stated that $\mathrm{HBV}$ vaccination is dangerous in already vaccinated people, which clearly is not supported by the facts. In the context of the fact that $77.7 \%$ also believe that $\mathrm{HBV}$ vaccine is the only way to prevent infection after exposure, we argue that the average dental student is not equipped with the knowledge needed to detect and appropriately react in the case of exposure to the virus. The importance of these findings is even more obvious in the context of the prevalence of needlestick injuries. Of the examined students, $18.4 \%$ had sustained a needlestick injury and only every fifth student reported the injury, indicating that additional energy should be invested in education on the importance of occupational injury reporting. Additionally, the reason for the lack of reporting should be sought and both clinical staff and students should become more familiar with the reporting protocols. Analysis of hepatitis-related knowledge by years revealed some interesting trends. We hypothesized that $4^{\text {th }}, 5^{\text {th }}$, and $6^{\text {th }}$ year students will have the highest scores on the hepatitis-related knowledge questionnaire as the Internal Medicine course $\left(4^{\text {th }}\right.$ year) curriculum provides most information on $\mathrm{HBV}$ and $\mathrm{HCV}$ in comparison to other courses. Moreover, we hypothesized that students having attended the Occupational Diseases in Den- 
tistry course $\left(3^{\text {rd }}\right.$ year) would have higher scores than their peers. However, the greatest knowledge difference was observed between $1^{\text {st }}$-year students and students enrolled in all other years, indicating that neither the Internal Medicine course nor the Occupational Diseases in Dentistry course resulted in increased knowledge on HBV and HCV (Fig. 3A). Moreover, unexpectedly, we could not compare the students having completed ODDE with their colleagues from the $3^{\text {rd }}$ year as most of the students who agreed to participate in the survey $(22 / 24)$ had attended the course. However, as knowledge of $3^{\text {rd }}$-year students was comparable to that of students enrolled in $2^{\text {nd }}$ year, we believe that unfortunately, attending the supplementary course did not result in the expected benefits. As briefly discussed in the Results section, $4^{\text {th }}$ and $5^{\text {th }}$-year students who had completed ODDE were slightly more likely to report needlestick injury in comparison with their peers who had just completed IME. However, the absence of the effect in the $6^{\text {th }}$ year students indicated that the observed effect was probably due to chance, and the number of students in this study was too small to draw meaningful conclusions from this observation. Either way, the high prevalence of needlestick injuries in clinical years and poor reporting suggest that clinical year students should be one of the target populations for additional education on occupational diseases. This might be especially important as there is an increasing trend of injuries with the increasing load of clinical work and educational interventions after graduation are much more difficult to implement. One of our hypotheses prior to this study was that education on important bloodborne pathogens and infectious occupational hazards would correlate with the number of the needlestick injuries reported. However, our data suggest that although there was an obvious correlation between needlestick injuryrelated knowledge and hepatitis-related knowledge, neither was in correlation with the increased number of needlestick injuries reported (Fig. 3C-D). As the number of reported injuries should be one of the main goals of education on occupational diseases, this raises an important question whether less time should be spent on teaching students about harmful health effects of infection and more time on teaching how and why the injury should be reported.

Finally, the limitations of our study should be noted. Our study was cross-sectional by design, so no true causal conclusions could be extracted from our data. Moreover, our study was based on a questionnaire, and participation in the study was voluntary, so although we had 206 participants, we cannot claim their responses are absolutely representative of the whole population of the University of Zagreb dental medicine students.

\section{Conclusion}

In conclusion, our cross-sectional study on basic hepatitis-related knowledge among dental medicine students at the University of Zagreb indicates that the level of knowledge on important occupational pathogens is low and we should look for a better way to increase student awareness and level of knowledge on this topic. Moreover, our results suggest that both our supplementary course and standard obligatory courses such as internal medicine rotation failed to significantly increase student knowledge in this important field, so we should design more robust studies to further understand the significance and true meaning of these observations and proactively approach this problem to increase reporting and knowledge of the important occupational pathogens in our students.

Data Availability Statement: all questionnaires and additional analyses are available in the Appendix. Any additional data are available upon request from the corresponding author. 


\section{APPENDIX}

\section{HBV-related Knowledge Questionnaire with Answers (correct answers underlined)}

A person with no symptoms of $\mathrm{HBV}$ infection cannot infect others.

True

False

I do not know

There is no laboratory test to distinguish between an acute and chronic HBV infection.

True

$\underline{\text { False }}$

I do not know

If a pregnant woman becomes infected with $\mathrm{HBV}$, it is not possible to prevent transmission

of the virus to the baby.

True

$\underline{\text { False }}$

I do not know

The symptoms of the disease usually develop 48 hours after exposure to HBV.

True

False

I do not know

$\mathrm{HBV}$ cannot induce malignant liver disease.

True

False

I do not know

HBV can be transmitted through contact

(for example, by handshake).

True

False

I do not know

HBV can be transmitted through contact

with open wounds and cuts.

True

False

I do not know

HBV can be transmitted through infected blood and bodily fluids.

$\underline{\text { True }}$

False

I do not know

HBV cannot be transmitted through non-sterile syringes, needles or surgical instruments.

True

False

I do not know
HBV can be transmitted through sexual contact without protection.

$\underline{\text { True }}$

False

I do not know

Vaccination cannot prevent $\mathrm{HBV}$ infection.

True

$\underline{\text { False }}$

I do not know

There is no laboratory test to prove $\mathrm{HBV}$ infection.

True

$\underline{\text { False }}$

I do not know

A post-exposure prophylaxis for $\mathrm{HBV}$ exists.

True

False

I do not know

Chronic HBV infection cannot be treated.

True

$\underline{\text { False }}$

I do not know

Acute $\mathrm{HBV}$ infection is always symptomatic and requires hospital admission.

True

False

I do not know

An acute $\mathrm{HBV}$ infection always transforms into chronic infection.

True

$\underline{\text { False }}$

I do not know

Younger people are more likely to develop chronic $\mathrm{HBV}$ infection after an acute $\mathrm{HBV}$ infection, in comparison to older people.

True

False

I do not know

$\mathrm{HBV}$ infection in the first year of life

will result in chronic infection in approximately $90 \%$ of cases.

$\underline{\text { True }}$

False

I do not know 
HBV infection in adulthood will result in development of chronic infection in about $\mathbf{9 0 \%}$ of cases.

True

$\underline{\text { False }}$

I do not know

$\mathrm{HBV}$ can be contracted by using a toothbrush of a person infected with HBV.

True

False

I do not know

$\mathrm{HBV}$ is often transmitted by

breastfeeding.

True

$\underline{\text { False }}$

I do not know

It is possible to contract $\mathrm{HBV}$ by

hugging.

True

False

I do not know

People living with those infected with $\mathrm{HBV}$ are at an increased risk of infection.

True

False

I do not know

Health care professionals are at a greater risk of $\mathrm{HBV}$ infection.

True

False

I do not know

In case of exposure to $\mathrm{HBV}$, it is possible to prevent development of the infection by vaccination within 24 hours.

True

False

I do not know

Once recovered from $\mathrm{HBV}$ infection, a person cannot get infected again.

True

False

I do not know

There is no effective way to prevent HBV.

True

$\underline{\text { False }}$

I do not know
A vaccine for $\mathrm{HBV}$ still does not exist.

True

False

I do not know

It is dangerous to receive $\mathrm{HBV}$ vaccine if someone has been vaccinated previously.

True

$\underline{\text { False }}$

I do not know

After exposure to $\mathrm{HBV}$, a post-exposure prophylaxis can be provided by vaccination or by administration of hepatitis B immunoglobulin.

True

False

I do not know

Health care professionals should be tested to determine if they have sufficient immunity to HBV. $\underline{\text { True }}$

False

I do not know

If insufficient immunity in adulthood has been determined, it is not possible to receive an additional dose of vaccine to develop immunity. True

False

I do not know

HBV vaccine cannot be received at the same time as other vaccines.

True

$\underline{\text { False }}$

I do not know

$\mathrm{HBV}$ vaccine is the only way to prevent development of infection after exposure to infected blood.

True

False

I do not know

$\mathrm{HBV}$ vaccine usually also protects against $\mathrm{HCV}$

(hepatitis $\mathrm{C}$ virus).

True

False

I do not know

$\mathrm{HCV}$ vaccine is more effective and safer than $\mathrm{HBV}$ vaccine.

True

False

I do not know 


\section{HCV-related Knowledge Questionnaire with Answers (correct answers underlined)}

The infection becomes chronic in more than $75 \%$ of people infected with $\mathrm{HCV}$.

True

False

I do not know

Acute $\mathrm{HCV}$ infection usually occurs within 6 months from exposure to $\mathrm{HCV}$.

True

False

I do not know

Some people do not develop chronic form of $\mathrm{HCV}$ infection, even though they have not received any form of therapy.

True

False

I do not know

It is not possible to contract $\mathrm{HCV}$ by using infected syringes.

True

$\underline{\text { False }}$

I do not know

A mother infected with $\mathrm{HCV}$ cannot transmit the infection to the child during childbirth.

True

$\underline{\text { False }}$

I do not know

It is possible to contract $\mathrm{HCV}$ by using an infected toothbrush.

True

False

I do not know

It is possible to contract HCV by getting a tattoo.

$\underline{\text { True }}$

False

I do not know

It is not possible to contract $\mathrm{HCV}$ through sexual contact.

True

$\underline{\text { False }}$

I do not know

Blood transfusion recipients are at an increased risk of $\mathrm{HCV}$ infection.

True

$\underline{\text { False }}$

I do not know
Blood clotting factor recipients are at an increased risk of $\mathrm{HCV}$ infection.

True

False

I do not know

An HCV infected mother will infect her child during childbirth in more than $50 \%$ of cases.

True

False

I do not know

It is possible to contract $\mathrm{HCV}$ from a bite

of the mosquito that previously sucked the blood of an infected person.

True

False

I do not know

Symptoms of an acute $\mathrm{HCV}$ infection occur 48 hours after exposure to the virus.

True

False

I do not know

Symptoms that appear 10 weeks after exposure to $\mathrm{HCV}$ are considered to be chronic infection.

True

$\underline{\text { False }}$

I do not know

Most people with acute $\mathrm{HCV}$ infection do not develop symptoms.

True

False

I do not know

A person with no symptoms cannot infect others.

True

False

I do not know

Chronic $\mathrm{HCV}$ infection can induce failure of liver function, malignant liver disease and death.

True

False

I do not know

$\mathrm{HCV}$ infection is easily transmitted through breastfeeding, so all infected mothers should refrain from breastfeeding.

True

False

I do not know 
There is no laboratory test that could detect if someone has been infected with $\mathrm{HCV}$.

True

$\underline{\text { False }}$

I do not know

There is no laboratory test to detect the ongoing $\mathrm{HCV}$ infection.

True

$\underline{\text { False }}$

I do not know

$\mathrm{HCV}$ antibodies in blood indicate there is an ongoing $\mathrm{HCV}$ infection.

True

False

I do not know

After exposure to $\mathrm{HCV}$, antibodies usually appear in the blood after 48 hours.

True

False

I do not know

A laboratory test for detection of HCV RNA (PCR) is usually positive on the same day the person has been exposed to $\mathrm{HCV}$.

True

$\underline{\text { False }}$

I do not know

In a person with normal liver enzyme values (ALT, AST), the possibility of chronic HCV can be excluded.

True

$\underline{\text { False }}$

I do not know

When it comes to acute HCV infection, targeted therapy is usually not recommended alongside symptomatic treatment.

True

False

I do not know

Therapy for chronic HCV exists, however, only $20 \%$ of people are cured.

True

$\underline{\text { False }}$

I do not know

The $\mathrm{HCV}$ vaccine is as effective as the $\mathrm{HBV}$ vaccine.

True

$\underline{\text { False }}$

I do not know
In Croatia, every person born after 1993

was vaccinated against $\mathrm{HCV}$.

True

$\underline{\text { False }}$

I do not know

In case of exposure to $\mathrm{HCV}$, there is a safe and effective post-exposure prophylaxis.

True

$\underline{\text { False }}$

I do not know

Following a needlestick exposure to

$\mathrm{HCV}$ positive blood, the risk of $\mathrm{HCV}$ infection is less than $2 \%$.

True

False

I do not know

A)

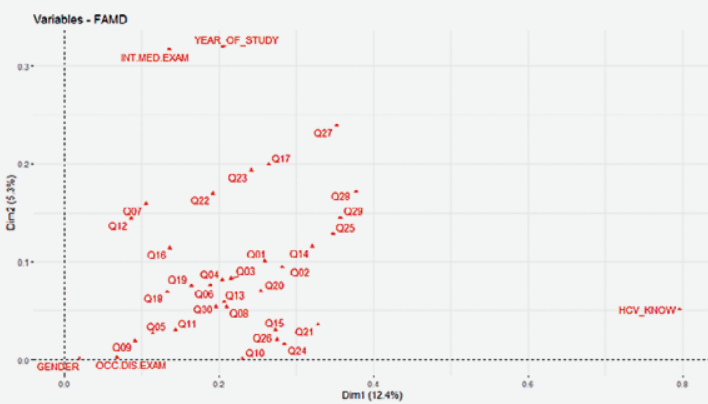

B)

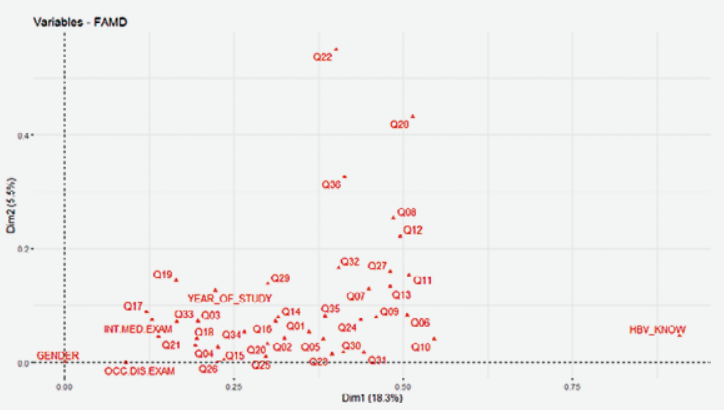

Fig I. Factor analysis of mixed data conducted on all questions from the $\mathrm{HCV}$ - and $\mathrm{HBV}$-related knowledge questionnaire, overall knowledge score, and information on the year of study, gender, and Internal Medicine and Occupational Diseases in Dentistry course completion: (A) graph of variables for the HCV-related knowledge questionnaire; (B) graph of variables for the $H B V$-related knowledge questionnaire. 
A)

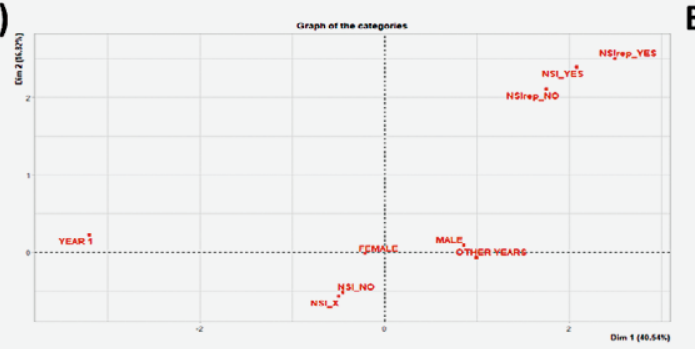

B)

D)

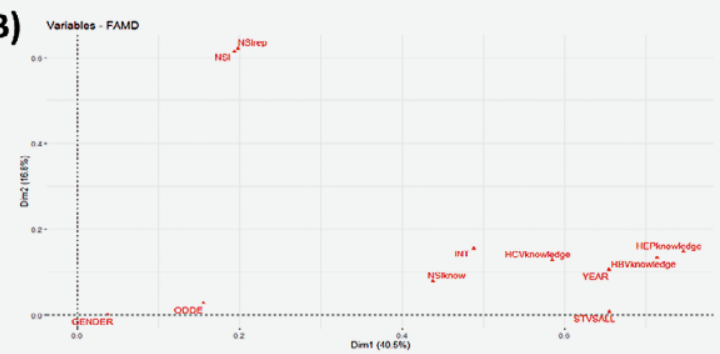

Dme (40.5)
C)

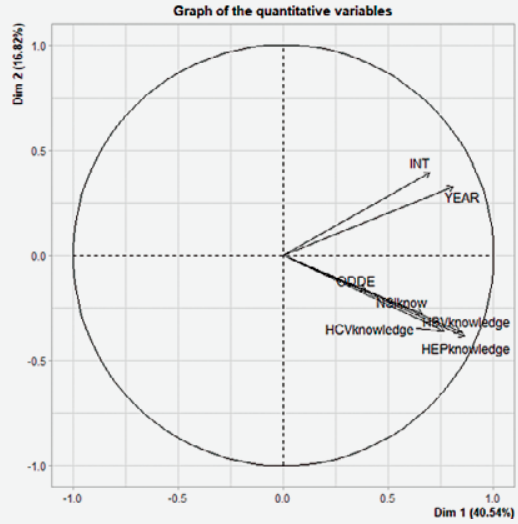

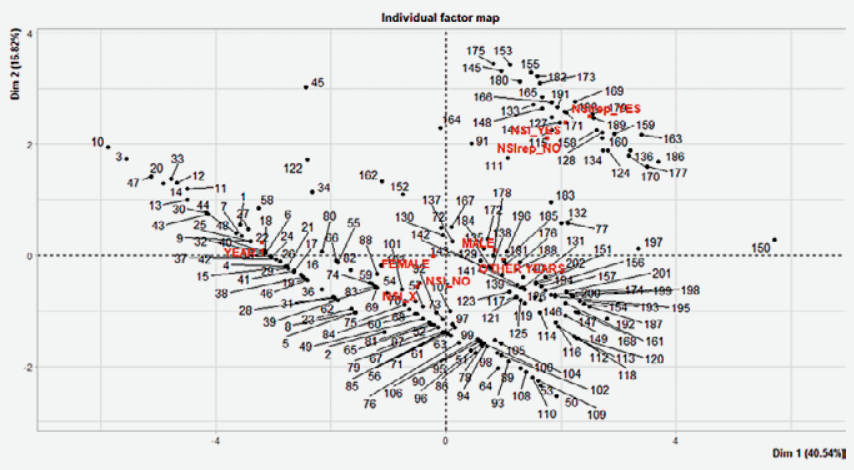

Fig II. Factor analysis of mixed data for categorical and quantitative variables: (A) graph of categories representing spatial relationship of variables in the context of the first and second informational dimensions; (B) graph of variables demonstrating spatial relationship of both quantitative and categorical variables in the context of the first two informational dimensions; (C) primary component analysis of quantitative variables; (D) graph of individual students in regard to descriptive categorical information.

YEAR1 $=1^{\text {st }}$-year students; OTHER YEARS $=$ students enrolled in all other years; NSI_X/NSI_NO = students who had not sustained needlestick injury; NSI_YES = students who had sustained a needlestick injury; NSIrep_YES = students who had sustained and reported a needlestick injury; NSIrep_NO = students who had sustained but did not report a needlestick injury; INT = Internal Medicine Exam; ODDE = Occupational Diseases in Dentistry Exam; NSI_knowledge = needlestick injuryrelated knowledge; HEPknowledge = overall hepatitis-related knowledge

\section{References}

1. MacLachlan, JH, Cowie BC. Hepatitis B virus epidemiology. Cold Spring Harb Perspect Med. 2015 May 1;5(5):a021410. doi: 10.1101/cshperspect.a021410.

2. Lavanchy D. Chronic viral hepatitis as a public health issue in the world. Best Pract Res Clin Gastroenterol. 2008;22: 991-1008. doi: 10.1016/j.bpg.2008.11.002

3. Petruzziello A, Marigliano S, Loquercio G, Cozzolino A, Cacciapuoti $\mathrm{C}$. Global epidemiology of hepatitis $\mathrm{C}$ virus infection: an up-date of the distribution and circulation of hepatitis $\mathrm{C}$ virus genotypes. World J Gastroenterol. 2016;22:7824-40. doi: 10.3748/wjg.v22.i34.7824

4. GBD Results Tool | GHDx. http://ghdx.healthdata.org/gbdresults-tool.

5. Lewis JD, Enfield KB, Sifri CD. Hepatitis B in healthcare workers: transmission events and guidance for management. World J Hepatol. 2015;7:488-97. doi: 10.4254/wjh.v7.i3.488
6. Westermann C, Peters C, Lisiak B, Lamberti M, Nienhaus A. The prevalence of hepatitis $\mathrm{C}$ among healthcare workers: a systematic review and meta-analysis. Occup Environ Med. 2015; 72:880-8. doi: 10.1136/oemed-2015-102879

7. Alavian SM, Izadi M, Zare AA, Lankarani MM, Assari S, Vardi MM. Survey of the level of anti-HBs antibody titer in vaccinated Iranian general dentists. Spec Care Dentist. 2008 Nov-Dec; 28(6):265-70. doi: 10.1111/j.1754-4505.2008.00052.x.

8. Mahboobi N, Agha-Hosseini F, Mahboobi N, Safari S, Lavanchy D, Alavian SM. Hepatitis B virus infection in dentistry: a forgotten topic. J Viral Hepat. 2010 May;17(5):307-16. doi: 10.1111/j.1365-2893.2010.01284.x.

9. Cleveland JL. Hepatitis B vaccination and infection among U.S. dentists, 1983-1992. J Am Dent Assoc. 1996;127:138590. doi: 10.14219/jada.archive.1996.0457

10. Shah SM, Bonauto D, Silverstein B, Foley M. Workers' compensation claims for needlestick injuries among healthcare 
workers in Washington State, 1996-2000. Infect Control Hosp Epidemiol. 2005 Sep;26(9):775-81. doi: 10.1086/502616.

11. Batista SMF, Andreasi MSA, Borges AMT, et al. Seropositivity for hepatitis $B$ virus, vaccination coverage, and vaccine response in dentists from Campo Grande, Mato Grosso do Sul, Brazil. Mem Inst Oswaldo Cruz. 2006;101:263-7. doi: 10.1590/ S0074-02762006000300006.

12. Abreu MH, Lopes-Terra MC, Braz LF, Rímulo AL, Paiva SM, Pordeus IA. Attitudes and behavior of dental students concerning infection control rules: a study with a 10 -year interval. Braz Dent J. 2009;20(3):221-5. doi: 10.1590/s0103-6440200900 0300009.

13. Li X, Kang H, Wang S, Deng Z, Yang T, Jia Y, Yang Y. Knowledge, attitude, and behavior of hepatitis $b$ virus infection among
Chinese dental interns. Hepat Mon.2015 May 23;15(5):e25079. doi: 10.5812/hepatmon.15(5)2015.25079.

14. Bichoupan K, Tandon N, Crismale JF, et al. Real-world cure rates for hepatitis $\mathrm{C}$ virus treatments that include simeprevir and/or sofosbuvir are comparable to clinical trial results. World J Virol. 2017 Nov 12; 6(4):59-72. doi: 10.5501/wjv.v6.i4.59.

15. Ghany MG, Morgan TR, AASLD-IDSA Hepatitis C Guidance Panel. Hepatitis C Guidance 2019 Update: American Association for the Study of Liver Diseases-Infectious Diseases Society of America Recommendations for Testing, Managing, and Treating Hepatitis C Virus Infection. Hepatology. 2020 Feb;71(2):686-721. doi: 10.1002/hep.31060.

Sažetak

\title{
PRESJEČNA STUDIJA EVALUACIJE ZNANJA O HEPATITISU B I C U POPULACIJI STUDENATA DENTALNE MEDICINE NA SVEUČILIŠTU U ZAGREBU
}

\author{
J. Homolak, D. Tomljanović, M. Milošević, D. Vražic, M. Živković, I. Budimir, B. Pezo Nikolić, \\ A. Muslim, N. Ljubičici i M. Nikolić
}

Stomatolozi, a osobito studenti dentalne medicine (DMS) izloženi su povećanom riziku od infekcije hepatitis B virusom (HBV) i hepatitis $\mathrm{C}$ virusom (HCV). Cilj naše studije bio je procijeniti razinu znanja o HBV i HCV, učestalost ubodnih ozljeda te praksu prijavljivanja ozljeda u populaciji DMS na Sveučilištu u Zagrebu te analizirati povezanost ovih parametara sa slušanjem obvezne i izborne nastave. Znanje studenata procijenili smo pomoću upitnika koje smo dizajnirali na temelju brošura CDC-a (Centers for Disease Control and Prevention) namijenjenih za informiranje opće populacije. Uz to prikupili smo informacije nužne za procjenu učestalosti i prijavljivanja ubodnih ozljeda. Podaci su analizirani deskriptivnim statističkim testovima, t-testom za nezavisne uzorke, analizom proporcija i kombiniranom faktorskom analizom za kvantitativne i kategoričke varijable pomoću SPSS-a i R-a. U istraživanju je sudjelovalo 206 studenata. Ukupno znanje studenata o HBV i HCV bilo je slabo s prosječno $61,90 \%$ odnosno $51,35 \%$ točnih odgovora na testovima. Znanje studenata prve godine bilo je značajno slabije u usporedbi sa znanjem njihovih starijih kolega. Od svih sudionika istraživanja $18,2 \%$ doživjelo je ubodnu ozljedu, a većina njih $(78,95 \%)$ nikada nije prijavila ozljedu. Zaključno, studenti stomatologije raspolažu slabim znanjem o važnim profesionalnim infektivnim bolestima te nedovoljno prijavljuju ozljede na radu. Uz to, izgleda da formalna izobrazba u sadašnjem obliku ne uspijeva značajno popraviti kompetencije studenata, a teorijsko znanje slabo se preslikava u svjesniju praksu prijavljivanja ozljeda. Rezultati naše studije upozoravaju na to da trebamo aktivno tražiti nove i bolje načine kako povećati svjesnost i razinu znanja o ovim važnim temama u naših studenata.

Ključne riječi: Hepatitis B; Hepatitis C; Stomatološka izobrazba; Ubodna ozljeda; Profesionalni patogeni; Zaštita zdravlja na radu 